\title{
Factors affecting spatial pattern of groundwater hydrochemical variables and nitrate in agricultural region of Korea
}

\author{
${ }^{1}$ Department of Geology, Kangwon National University, Chuncheon 24341, Republic of Korea \\ ${ }^{2}$ Critical Zone Frontier Research Laboratory, Kangwon National University, Chuncheon 24341, Republic of Korea; *Corresponding author, \\ E-mail:hydrolee@kangwon.ac.kr
}

(Received: May 8, 2019; Revised accepted: May 18, 2019)

https://doi.org/10.18814/epiiugs/2019/019011

The overuse of fertilizers for high yields in agricultural production increases the leaching problem particularly in areas affected by heavy monsoon precipitations in Republic of Korea. The extent of leaching depends on various factors such as rate of monsoon precipitation, agricultural management practices, land use, soil properties, topographic features, and hydrochemistry. We studied spatial variations based on temporal fluctuations of groundwater level below the ground surface, $p H$, electrical conductivity (EC), and nitrate $\left(\mathrm{NO}_{3}\right)$ from year 2011 to 2014 in 70 groundwater wells in agricultural region of Korea. We found that groundwater level deepening across the studied period in agricultural area. Low $p H$ (5.50-6.50) gradually vanished in year 2014 and high $p H$ (8.51-9.50) appeared in the same year. Variations in the EC values shifted from high range EC $(>500 \mu \mathrm{S} / \mathrm{cm})$ to lower range $(<100 \mu \mathrm{S} / \mathrm{cm})$ from 2011 to 2014. Similar to spatial pattern of groundwater EC and contrary to $\mathrm{pH}$, the high values $(>50 \mathrm{mg} / \mathrm{L})$ for groundwater $\mathrm{NO}_{3}$ which appeared in the start of the study period, got vanished at the end of the study period. These findings are attributed to improved agricultural practices and change in land use pattern from vegetables to orchards and ginseng fields which do not require excessive fertilizer application.

\section{Introduction}

Fertilizers are applied extensively to increase crop production in agricultural areas, which results in excessive $\mathrm{NO}_{3}$ in soil and water systems. One of the most prevalent and harmful impacts of $\mathrm{NO}_{3}$ polluted groundwater (used for drinking purpose) is to pose risks of human and ecological health (Schroder et al., 2004). Drinking water having concentrations $>10 \mathrm{mg} / \mathrm{L}$ for $\mathrm{NO}_{3}$, causes human health problems such as blue baby syndrome and cancer in adults specially in the digestive tract (Powlson et al., 2008; World Health Organization, 2011; Kim et al., 2015). The high concentration of $\mathrm{NO}_{3}$ in groundwater is a severe problem in Korean agricultural areas (Lee et al., 2017). Monitoring groundwater contamination and identifying factors influenced the $\mathrm{NO}_{3}$ concentration in groundwater are important steps to reduce contamination and manage groundwater quality.

Several factors have been identified affecting $\mathrm{NO}_{3}$ contamination in groundwater, including amount of applied fertilizer and accumulation of soil organic content, which can lead to high $\mathrm{NO}_{3}$ concentration and thus have higher rate of nitrate leaching to groundwater (Sieling and Kage, 2006). In addition to that, use of animal manure, crop growing duration (Rankinen et al., 2007), soil properties (De Ruijter et al., 2007), rate of monsoonal precipitation (Salo and Turtola, 2006), and topographic features such as elevation and land slopes in complex terrain area (Wick et al., 2012) have been found to effect the degree of agricultural $\mathrm{NO}_{3}$ leaching to groundwater. Other potential factors have been investigated as sustainable agriculture practices, land use and land cover change, and change in hydrochemical variables of groundwater in changing climate (Rankinen et al., 2007; Buczko et al., 2010; Wick et al., 2012). Shallow groundwater level, the upper borderline of the saturated zone shows variation depending on seasonal changes in precipitation events (Kurunc et al., 2016). Fluctuation in groundwater level is important at watershed-scale, because of its nearness to the surface, chemical transport, drainage, and soil salinity.

Groundwater monitoring is fundamental to provide information for sustainable water management. Sustainable land and water management measures are based on the results of groundwater hydrochemical variables which provide the changes in groundwater quality and quantity. In agricultural areas, monitoring wells are generally used to assess spatiotemporal changes in groundwater level and groundwater quality variables (Kaman et al., 2011). Groundwater monitoring responds gradually to changes in agricultural practices and greatly influenced by weather events (Lord et al., 2002). Other than monitoring of groundwater wells data analysis is important to provide useful information of hydrochemical variables in the area. A systematic variation in spatial pattern allow to predict the value of a particular variable at specified location. Geostatistics has been used to analyze the systematic variation of water variables in space and time (Kurunc et al., 2016). Geostatistical analysis includes three steps: descriptive statistics, semivariograms for spatial structure, and predicting unknown value for specified variable at unvisited location. Spatial relationship between hydrochemical properties of groundwater is important for a sustainable water management planning. Kriging is widely geostatistical techniques for making spatial interpolation on sufficient data (Corwin et al., 1997). 
Haean basin is one of the most active highland agricultural areas in Soyang watershed, Korea with limited information on spatiotemporal distribution of hydrochemical variables and factors influencing their distribution. Hence, investigating the spatial and temporal variations in groundwater hydrochemical variables and $\mathrm{NO}_{3}$ related to fertilization and seasonal differences in agricultural area were the purposes of this study. From 2011 to 2014, a visible change in factors affecting $\mathrm{NO}_{3}$ in groundwater was observed in land use, rate of monsoonal precipitation, and fertilizer use. The study was conducted to evaluate temporal variations in spatial pattern of groundwater level, $\mathrm{pH}, \mathrm{EC}$, and $\mathrm{NO}_{3}$ concentrations in groundwater wells in the Haean basin. The special concern of this study was groundwater $\mathrm{NO}_{3}$ pollution and factors influencing high or low concentrations of $\mathrm{NO}_{3}$ in groundwater. The main objectives were to;

1) Find temporal variations in spatial pattern of groundwater hydrochemical variables and $\mathrm{NO}_{3}$

2) Determine the potential factors that are controlling and increasing the $\mathrm{NO}_{3}$ concentration in groundwater
The results of this study will help to understand the change in groundwater quality of an agricultural area and reasons behind improved or deteriorated groundwater quality. Such results might have important implications for agricultural areas with similar natural conditions including hydrogeological properties, climate conditions, and land use.

\section{Materials and Methods}

\section{Study Area}

The study area (Haean basin) is located in Yanggu County of Gangwon Province and extends from $128^{\circ} 5^{\prime}-128^{\circ} 11^{\prime} \mathrm{E}$ in latitudes and $38^{\circ} 15^{\prime}-38^{\circ} 20^{\prime} \mathrm{N}$ in longitudes (Fig. 1a). This area covers approximately $64 \mathrm{~km}^{2}$ of which $40 \%$ of the area is used for agriculture (rice paddy fields, vegetables, and fruits) (Kim et al., 2015). Remaining $2 \%$ is used for residential and $58 \%$ of area is covered with forested mountains surrounding the flat agricultural area. The geology of area in

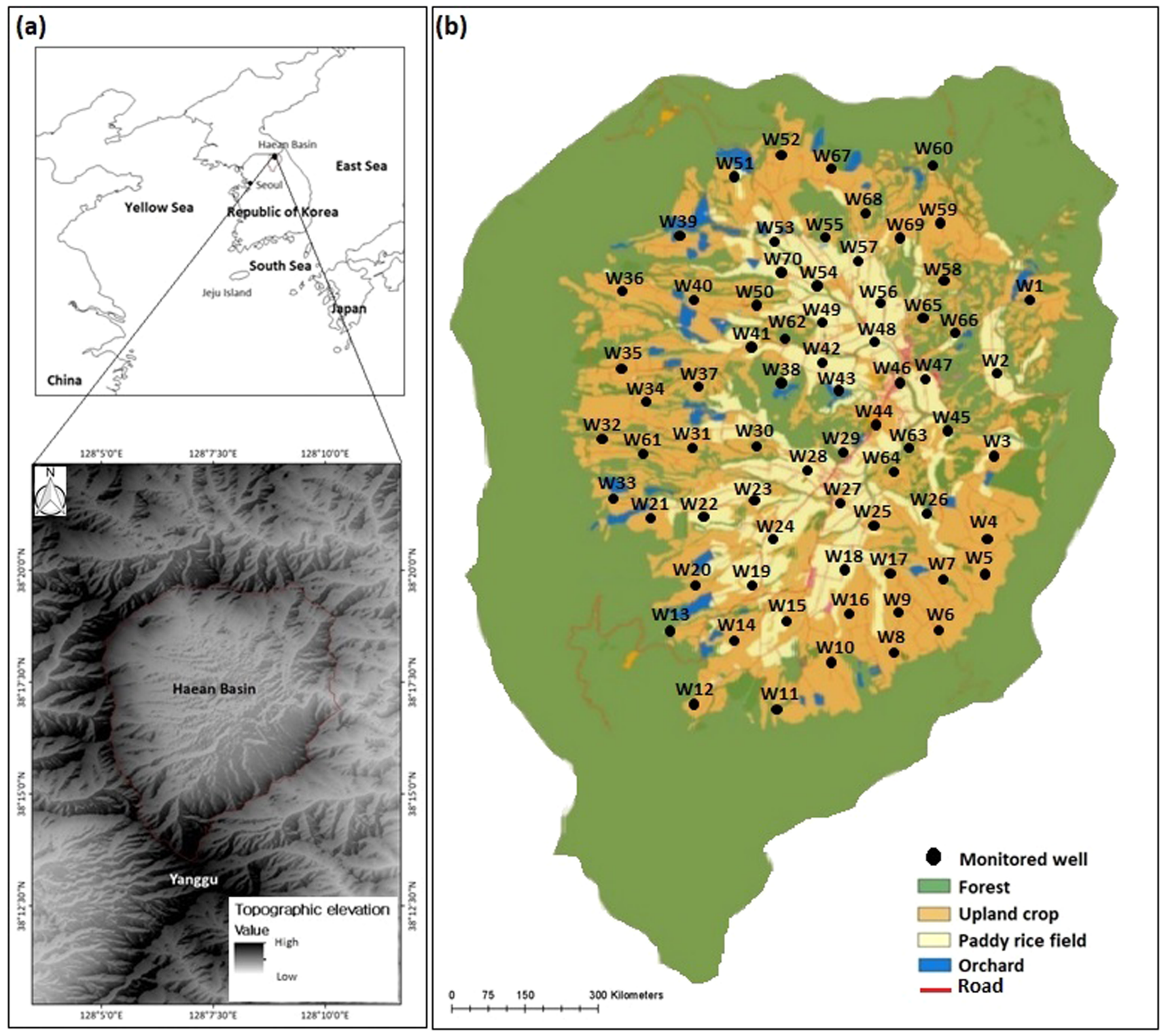

Figure 1. (a) Location of the Haean Basin in Republic of Korea, (b) Georeferenced locations of monitored wells and land use in the study area. 
center is accredited to weathering of meta-sedimentary rocks and Jurassic granites and outer area comprised of meta-sedimentary rocks including mica schists, biotite-feldspar gneiss and quartzite (Lee et al., 2013). The base land contains alluvial deposits 5-10 m thick in area close to the relatively large (more than $2 \mathrm{~m}$ ) streams in the flat area (Kaown et al., 2007). The mountains surrounding the agricultural area have elevation up to $1,320 \mathrm{~m}$ (above the sea level) with average slope of $20^{\circ}$ in surrounding ridges and average slope of $5^{\circ}$ in the center agricultural area (Kettering et al., 2012). The study area is in Humid Continental climate zone with mean annual temperature of $8.7^{\circ} \mathrm{C}$ which goes down to $-27^{\circ} \mathrm{C}$ in January and goes up to $33^{\circ} \mathrm{C}$ in July (Ko et al., 2014; Lim et al., 2018). The average annual rainfall is $1,200 \mathrm{~mm}$ with $50 \%$ falling during the season of summer monsoon (Kim et al., 2018; Lee et al., 2018).

Groundwater is the major source of irrigation water and domestic water supply in the study area. There are some small streams that went dry during dry season, join to three large streams Dosol, Mandae, and Seonghwang (10-15 m wide) at the center of study area. Eventually these streams leave the study area at the eastern side and congregate with the Soyang River which is the major source of drinking water supply in the Seoul metropolitan city (Lee et al., 2013). The number of groundwater wells in study area increased due to increased agricultural activities.

\section{Land Use}

Approximately $58 \%$ (around $38 \mathrm{~km}^{2}$ ) of the study area is covered with forests, especially on the high elevation lots of the bowl-shaped Haean basin (Kim et al., 2013). The highland forest predominately composed of 30 to 40 year old mixed deciduous forest with major species; Daimyo oak (Quercus dentata), Korean ash (Fraxinus rhynchophylla), and Mongolian oak (Quercus mongolica) (Shope et al., 2014). The remaining $2 \%$ is used for residential purpose and $38 \%$ of the study area principally in the lower elevation portion is used for agriculture conquered by rice paddy, vegetable fields, and orchards on intermediate elevation (Kim et al., 2015). Rice paddy fields are mostly located on lower elevation with flattened area, vegetable fields are located between paddy rice field orchards, and orchard are located on intermediate to high elevation before forests (Fig. 1b). Among agricultural crops in the study area rice prevails maximum $(31.5 \%-51.5 \%$, mean $=38.7 \%$ ) of agricultural land followed by vegetable fields and orchards (Lee, et al., 2019). The main crops in vegetable field radish and cabbage have growing season starting before monsoon season and ends after monsoon. Rice crop has similar growing season. The area covered by vegetable fields got decreased during study period from 2011 to 2014 with an increase in orchard area (Lee et al., 2019). After 2010, the subsidies for the application of chemical fertilizer have been reduced by the government, but increased for the use of organic fertilizers. This has resulted in increasing use of organic fertilizers, while a decrease in use of synthetic fertilizers in the Haean basin. According to an estimation the annual rate of organic fertilizer application in the Haean basin has increased from $95 \mathrm{~kg} \mathrm{~N} \mathrm{ha}^{-1}$ in 2011 to $134 \mathrm{~kg} \mathrm{~N} \mathrm{ha}^{-1}$ in 2012 and so on in the next years (Yanggu County Office, 2014).

\section{Hydrochemical Data of Groundwater}

There were 70 groundwater wells observed and georeferenced with geographical positioning system (GPS) device during first trip to the field of study. The monitored well location data was transferred to computer for processing in ArcGIS (version 10.4) to build digital map of study area (Figs. 1a and 1b). Groundwater samples were collected twice a year, once in dry season (September-May) and other in wet season (June-August) in year 2011, 2012, 2013, and 2014. Groundwater level was measured in all monitored wells using water level meter (Solinst model 101 P7) (Yun et al., 2017). The container used for groundwater sampling was first rinsed with the water sample and then analyzed for $\mathrm{pH}$ and EC using portable multi meter probe (HORIBA D-74 and D75). One groundwater sample was taken from each well in a plastic bottle and $2 \mathrm{~mL}$ toluene was added to stop microbial activities. Each plastic bottle was labeled and stored in ice-box during transportation to laboratory and all groundwater samples were stored at $<4^{\circ} \mathrm{C}$ before analysis. A Whatman-42 filter paper was used to filter the sample before $\mathrm{NO}_{3}$ analysis in Ion Chromatograph (model DX-120, Dionex Corporation).

\section{Geostatistical Analysis}

There are three main stages involved in geostatistical analysis for this study. First stage consists of exploratory data analysis including the descriptive statistics. Second stage involves geostatistical modeling to measure the spatial structure of water quality parameters and fitted to theoretical models. Third stage is followed by two steps; spatial prediction of missing values and mapping of overall spatial structure based on data and predicted values.

\section{Exploratory Statistics}

Exploratory statistics of mean, median, minimum, maximum, standard deviation of mean, coefficient of skewness, coefficient of kurtosis, and coefficient of variation were calculated for groundwater level below the ground surface, $\mathrm{pH}, \mathrm{EC}$, and $\mathrm{NO}_{3}$. The distributions of data were examined by Kolmogorov-Smirnov test with significant $\mathrm{P}$-value $(<0.05)$. Parametric statistical approach was used for normally distributed data and nonparametric approach was used where data distribution is not normal.

\section{Spatial Structure Identification}

Spatial structures of groundwater hydrochemical variables and $\mathrm{NO}_{3}$ were assessed using geostatistical modeling technique, to generate mathematical models for spatial correlation structure (Sheikhy et al., 2013). A variogram is one of the rudimentary geostatistical tool that measures the spatial variability of different parameters between two points. A semivariogram is exactly same as variogram except the denominator in the equation, the number 2 is excluded. Semivariogram reveals the spatial correlation as a function of distance between locations (Fentanes et al., 2018). A mathematical expression is given as:

$$
\gamma(h)=\frac{1}{2} \sum_{i=1}^{n(h)} \frac{\left[v\left(x_{i}\right)-v\left(x_{i}+h\right)\right]^{2}}{n(h)}
$$

where $n(h)$ is number of data pairs at $h$ distance, $v\left(x_{i}\right)$ is value at location $x_{i}, v\left(x_{i}+h\right)$ is value at location $x_{i}+h$.

There are three representative components generally considered for 
semivariogram; nugget is the semi-variance at 0 distance measured as nugget variance, range is the distance $(\mathrm{m})$ which is spatially correlated, and sill is the semi-variance at remoteness above the range, measured as structural variance sill. We used software GS+ to apply experimental semivariogram modeling on data. The best set of semivariogram including nugget, sill, and range components were generated by changing the active lag distance and lag class distance interval. Model fitting was done by changing model type, until minimum residual sum of squares (RSS) and maximum coefficient of determination $\left(r^{2}\right)$ were achieved. Anisotropic semivagrams were calculated at $n$ degrees $\left(0^{\circ}, 45^{\circ}, 90^{\circ}\right.$ and $\left.135^{\circ}\right)$ (Isaaks and Srivastava, 1989). The fitted variogram model was used to predict the parameter value at un-sampled locations.

\section{Prediction and Mapping of Spatial Pattern}

Geostatistical interpolation is a powerful technique to estimate and present the spatial pattern from point data (Belkhiri and Narany, 2015). The application of geostatistics is required when, spatial structure looks more similar for sampling points near to each other than sampling points far apart from each other. Kriging is an appropriate interpolation method which demonstrates the likelihood of interpolation of the approximation error of the variables where initial data is lacking. ArcGIS was used to conduct kriging interpolation and mapping of kriging predicted values for the groundwater hydrochemical variables and $\mathrm{NO}_{3}$. Expression of kriging estimations is given as Kumar (2007):

$$
\hat{Z}\left(S_{0}\right)=\sum_{i=1}^{N} \lambda_{i} Z\left(S_{i}\right)
$$

where $Z\left(S_{i}\right)$ is measured value at the $i$ location, $\lambda_{i}$ is the unknown weight of measured value at $i$ location, $S_{o}$ is predicted location, and $N$ is number of measured values.

Kriging estimates presented with $95 \%$ confidence intervals and digitally mapped for predicted values of nitrate and important water quality parameters. Maximum 14 and minimum 7 neighboring values of study area were used in kriging predictions. Digital kriging map was generated for groundwater level using class intervals of $0-5,6-10$, 11-20, and 21-30 $\mathrm{m}$ and maps were used for evaluating the presence of water quality variables. The kriging prediction map of groundwater $\mathrm{pH}$ was built with class intervals of 5.50-6.50, 6.51-7.50, 7.51-8.50, and 8.51-9.50. Digital map kriging prediction of groundwater EC was generated using class intervals of $<100.0,100.0-250.0,250.1-500.0$, and $>500 \mu \mathrm{S} / \mathrm{cm}$. The kriging prediction map of groundwater nitrate was built with class intervals of $<10.00,10.01-25.00,25.01-50.00$, and $>50.01 \mathrm{mg} / \mathrm{L}$. After generating maps, the areal coverage of each class was calculated in $\mathrm{km}^{2}$ along with its percentage to observe spatiotemporal variations.

\section{Results}

\section{Hydrochemical Characteristics}

The hydrochemical results of groundwater samples showed in Table 1, indicate descriptive statistics for the groundwater variables collected in rainy and dry seasons from year 2011 to 2014 . Groundwater hydro- chemical variables were measured in 70 monitoring wells located in the study area. Some monitoring wells were inaccessible for sampling in different seasons, except the first rainy season of sample collection. The groundwater level was highly variable and indicate lowering of groundwater level across the studied years. Mean for groundwater level fluctuated between seasons while median indicated deep groundwater level during dry seasons of years except for the dry season of 2014, when median of rainy season was higher than dry season and showing deep groundwater level. Data with high maximum values become strongly right skewed with high kurtosis and high variance values. This suggests high values (deep groundwater level) took place in the season that changed the median value from the mean value. Maximum values for groundwater level are generally more important than mean or median values since those values do not indicate the mutilation caused by high values in the study area. The minimum values of groundwater level fluctuated, while maximum values got increased and results in deepening of groundwater level across the studied period.

The $\mathrm{pH}$ is important variable which controls most of the biochemical processes in groundwater. Table 1 indicates the mean of groundwater $\mathrm{pH}$ increased gradually from 6.55 to 7.82 during the studied period, but slightly decreased in fourth season (dry season, 2012) and then sharply increased until the dry season of 2014. Variance, strong positive skewness, and high kurtosis values followed the high maximum values of $\mathrm{pH}$ that were mostly observed in rainy season of the years, except in 2011 when high maximum value occurred in dry season. The maximum $\mathrm{pH}$ value increased from 6.94 in the dry season of 2011 to 9.50 in dry season of 2014 , while minimum values do not show noticeable fluctuations.

The distribution of EC is indicator of overall contaminants present in the study area. In Table 1, the mean EC value gradually decreased from 604 to $80 \mu \mathrm{S} / \mathrm{cm}$ with a slight rise in fourth season (dry season, 2012). Extremely right skewed, variance, and kurtosis followed the similar pattern as of EC maximum values that decreased from 1,298 to $109 \mu \mathrm{S} / \mathrm{cm}$ during the studied period. Among different seasons, EC found to be higher in rainy season, except in year 2012 when it was higher in the dry season. The outlook of groundwater EC distribution suggests a gradual drop in value irrespective of seasonal variations.

Table 1 shows, the mean values for groundwater $\mathrm{NO}_{3}$ decreased gradually during the study period except in the second season (dry season, 2011). The $\mathrm{NO}_{3}$ values followed a similar decreasing pattern to $\mathrm{EC}$ value and opposite to $\mathrm{pH}$ and groundwater level increasing values, across the study period. Among seasonal variations, the maximum higher values of groundwater $\mathrm{NO}_{3}$ were observed in rainy seasons which decreased from 88.24 to $19.10 \mathrm{mg} / \mathrm{L}$. Skewness, kurtosis, and variance followed the similar decreasing pattern as of maximum $\mathrm{NO}_{3}$ value. Very high variance particularly for groundwater $\mathrm{EC}$ and $\mathrm{NO}_{3}$ are demonstrating large variability of the considered variables in the study area.

\section{Spatial Structure of Groundwater Hydrochemical Vari- ables and $\mathrm{NO}_{3}$}

Spatial structure of groundwater level varied across the eight studied seasons had a temporal stability in structure. Fig. 2 demonstrated the theoretical model and related parameters for the spatial structure during rainy and dry season of the studied years. The proportion of nugget variance and sill $\mathrm{C}_{0} /\left(\mathrm{C}_{0}+\mathrm{C}\right)$ increased unexpectedly in both 
Table 1. Overall descriptive statistics of hydrochemical data collected in rainy and dry season from 2011 to 2014

\begin{tabular}{|c|c|c|c|c|c|c|c|c|}
\hline Parameter & GWL (m) & $\mathrm{pH}$ & $\mathrm{EC}(\mu \mathrm{S} / \mathrm{cm})$ & $\mathrm{NO}_{3}(\mathrm{mg} / \mathrm{L})$ & GWL (m) & $\mathrm{pH}$ & $\mathrm{EC}(\mu \mathrm{S} / \mathrm{cm})$ & $\mathrm{NO}_{3}(\mathrm{mg} / \mathrm{L})$ \\
\hline 2011 & \multicolumn{4}{|c|}{ Rainy season (June-August) } & \multicolumn{4}{|c|}{ Dry season (September-May) } \\
\hline n (n.m.) & \multicolumn{4}{|c|}{$70(0)$} & \multicolumn{4}{|c|}{$65(5)$} \\
\hline Mean & 3.18 & 6.55 & 604 & 34.40 & 2.80 & 6.69 & 272 & 38.80 \\
\hline Median & 2.21 & 6.53 & 453 & 33.64 & 2.35 & 6.59 & 272 & 38.90 \\
\hline Min & 0.69 & 6.17 & 297 & 1.96 & 1.1 & 6.34 & 265 & 6.60 \\
\hline Max & 17.24 & 6.94 & 1298 & 88.24 & 10.45 & 7.18 & 282 & 70.81 \\
\hline SD & 2.84 & 0.31 & 391.65 & 32.17 & 1.83 & 0.33 & 7.08 & 26.57 \\
\hline $\mathrm{S}$ & 3.24 & 0.04 & 1.20 & 0.52 & 2.54 & 0.72 & 0.45 & -0.02 \\
\hline $\mathrm{K}$ & 13.25 & -1.82 & -0.09 & -0.93 & 8.25 & -0.78 & -1.25 & 0.71 \\
\hline $\mathrm{V}$ & 8.06 & 0.09 & 1.53 & 1.03 & 3.35 & 0.11 & 50.2 & 706.1 \\
\hline \multicolumn{9}{|c|}{2012} \\
\hline n (n.m.) & \multicolumn{4}{|c|}{$67(3)$} & \multicolumn{4}{|c|}{$66(4)$} \\
\hline Mean & 2.91 & 6.80 & 212 & 33.00 & 3.18 & 6.69 & 248 & 29.40 \\
\hline Median & 2.50 & 6.85 & 216 & 31.71 & 2.73 & 6.52 & 254 & 33.15 \\
\hline Min & 0.72 & 5.79 & 188 & 8.69 & 1.23 & 6.11 & 235 & 6.67 \\
\hline Max & 10.10 & 7.88 & 234 & 66.81 & 15.4 & 7.20 & 256 & 47.44 \\
\hline SD & 1.87 & 6.80 & 17.14 & 19.60 & 2.65 & 0.45 & 9.57 & 17.32 \\
\hline $\mathrm{S}$ & 1.92 & 0.18 & -0.11 & 0.22 & 4.08 & -0.01 & -0.8 & -0.20 \\
\hline $\mathrm{K}$ & 5.21 & -0.34 & -1.80 & -1.37 & 17.21 & -1.80 & -2.05 & -2.15 \\
\hline $\mathrm{V}$ & 3.51 & 0.32 & 293.86 & 384.31 & 7.06 & 0.2 & 91.7 & 300.23 \\
\hline \multicolumn{9}{|c|}{2013} \\
\hline n (n.m.) & \multicolumn{4}{|c|}{$62(8)$} & \multicolumn{4}{|c|}{$60(10)$} \\
\hline Mean & 4.22 & 6.98 & 179 & 23.26 & 4.23 & 7.16 & 161 & 14.92 \\
\hline Median & 3.15 & 6.90 & 180 & 21.50 & 3.17 & 7.02 & 159 & 13.94 \\
\hline Min & 1.03 & 6.05 & 176 & 8.97 & 1.20 & 6.70 & 150 & 0.11 \\
\hline Max & 13.28 & 8.14 & 182 & 39.69 & 19.82 & 7.71 & 175 & 33.88 \\
\hline SD & 3.52 & 0.49 & 2.44 & 10.09 & 3.89 & 0.34 & 7.95 & 11.57 \\
\hline $\mathrm{S}$ & 1.88 & 0.45 & -0.50 & 0.12 & 3.27 & 0.42 & 0.30 & 0.30 \\
\hline $\mathrm{K}$ & 2.57 & 0.42 & -1.40 & -1 & 12.25 & -1.29 & -1.19 & -0.71 \\
\hline $\mathrm{V}$ & 12.39 & 0.24 & 5.98 & 101.88 & 15.15 & 0.11 & 63.24 & 133.88 \\
\hline \multicolumn{9}{|c|}{2014} \\
\hline n (n.m.) & \multicolumn{4}{|c|}{$66(4)$} & \multicolumn{4}{|c|}{$65(5)$} \\
\hline Mean & 5.17 & 7.50 & 125 & 12.87 & 4.08 & 7.82 & 80 & 9.46 \\
\hline Median & 3.36 & 7.48 & 128 & 11.35 & 3.21 & 7.88 & 84 & 9.00 \\
\hline Min & 1.25 & 6.11 & 99 & 0.20 & 1.41 & 6.77 & 56 & 0.93 \\
\hline Max & 29.5 & 9.50 & 143 & 34.92 & 12.67 & 8.65 & 109 & 19.10 \\
\hline SD & 5.9 & 0.94 & 13.63 & 11.65 & 3.01 & 0.55 & 13.27 & 6.31 \\
\hline $\mathrm{S}$ & 3.39 & 0.93 & -0.35 & 0.54 & 2.07 & -0.71 & -0.54 & 0.46 \\
\hline $\mathrm{K}$ & 13.09 & 1.42 & -1.19 & -0.83 & 4.66 & 0.82 & -0.01 & -0.54 \\
\hline $\mathrm{V}$ & 34.91 & 0.89 & 185.93 & 135.82 & 9.08 & 0.30 & 176.27 & 39.91 \\
\hline
\end{tabular}


2011

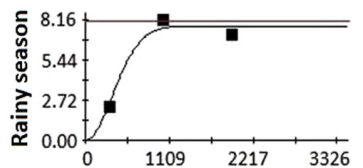

Gaussian model $\left(\mathrm{Co}_{0}=0.01 ; \mathrm{Co}+\mathrm{C}=\right.$ $7.70 ; A_{0}=510 ; r^{2}=0.96 ; R S S=0.68$

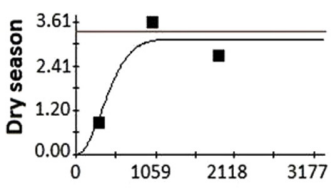

aussian model $\left(\mathrm{CO}_{0}=0.001 \cdot \mathrm{Co}+\mathrm{C}\right.$ 3.15; $\mathrm{Ao}=497 ; \mathrm{r}^{2}=0.87 ; \mathrm{RSS}=0.49$ )

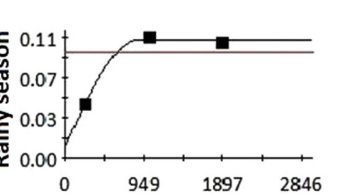

Spherical model ( $\mathrm{Co} 0.01 ; \mathrm{Co}+\mathrm{C}=$ $0.10 ; \mathrm{Ao}=873 ; \mathrm{r}^{2}=0.99 ; \mathrm{RSS}=0.83$ )
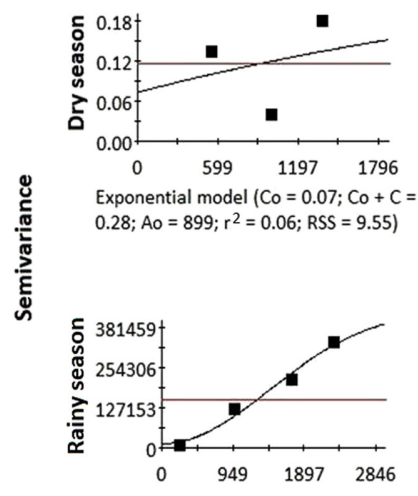

$\begin{array}{lll}0 & 949 \quad 1897 \quad 2846\end{array}$

Gaussian model $\left(C_{0}=13000 ; C o+C=\right.$

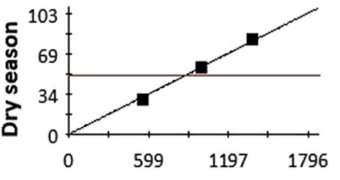

inear model $\left(\mathrm{CO}_{0}=0.1 ; \mathrm{Co}+\mathrm{C}=\right.$ $84.4 ; A o=1468 ; r^{2}=1 ; R S S=0.92$ )

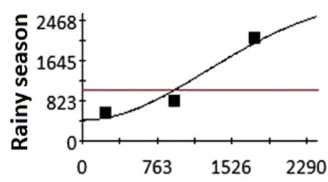

Gaussian model $(C O=424 ; C O+C=$ 2468; $A_{0}=1787 ; r^{2}=0.95 ;$ RSS $=>10$

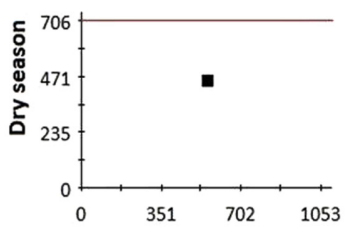

2012

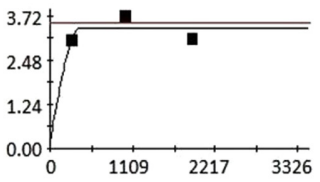

Spherical model $(\mathrm{Co}=0.19 ; \mathrm{Co}+\mathrm{C}=$ $A_{0}=397 ; r^{2}=0.82 ; R S S=0.2$

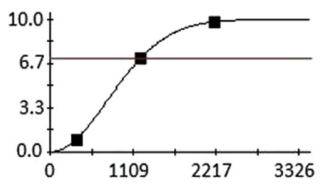

Gaussian model $\left(C_{0}=0.01 \cdot C_{0}+C\right.$ $10.02 ; A 0=1091 ; r^{2}=1 ; R S S=0.01$

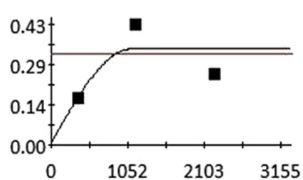

Spherical model $\left(\mathrm{CO}_{0}=0.01 ; \mathrm{Co}+\mathrm{C}=\right.$ $0.34 ; \mathrm{Ao}=1099 ; \mathrm{r}^{2}=0.80 ; \mathrm{SSD}=0.01$

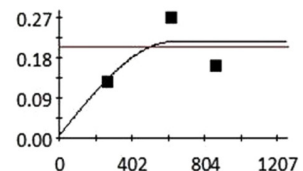

$\begin{array}{llll}0 & 402 & 804 & 1207\end{array}$

Spherical model $\left(\mathrm{CO}_{0}=0.005 ; \mathrm{Co}+\mathrm{C}\right.$ $0.21 ; A_{0}=622 ; r^{2}=0.80 ;$ RSS $=0.62$

2013

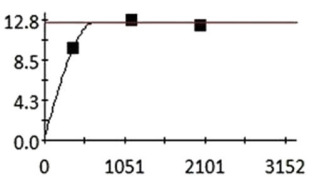

$\begin{array}{llll}0 & 1051 & 2101 & 3152\end{array}$

Spherical model $(\mathrm{Co}=0.46 ; \mathrm{Co}+\mathrm{C}=$

年

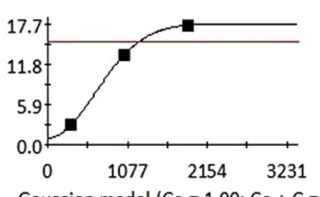

Gaussian model $\left(C_{0}=1.00 ; C 0+C=\right.$

$17.70 ; A 0=902 ; r^{2}=1 ; R S S=0.72$ )

$\mathrm{pH}$

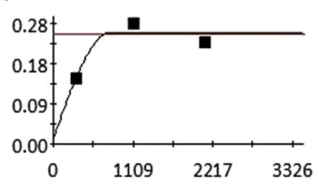

Sherical model $\left(\mathrm{CO}_{0}=0.01 ; \mathrm{Co}+\mathrm{C}=\right.$

$0.25 ; A 0=788 ; r^{2}=0.90 ; R S S=0.91$ )

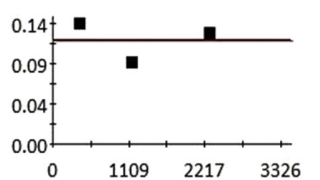

$1109 \quad 2217 \quad 3326$

Linear model $(C o=0.12 ; C o+C=0.12 ;$
$\left.A o=2294 ; r^{2}=0.09 ; R S S=1.10\right)$

$\mathrm{EC}(\mu \mathrm{S} / \mathrm{cm})$

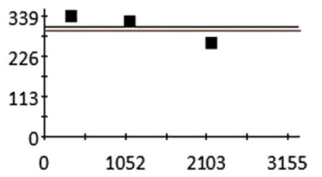

Linear model $(\mathrm{Co}=307 ; \mathrm{Co}+\mathrm{C}=$
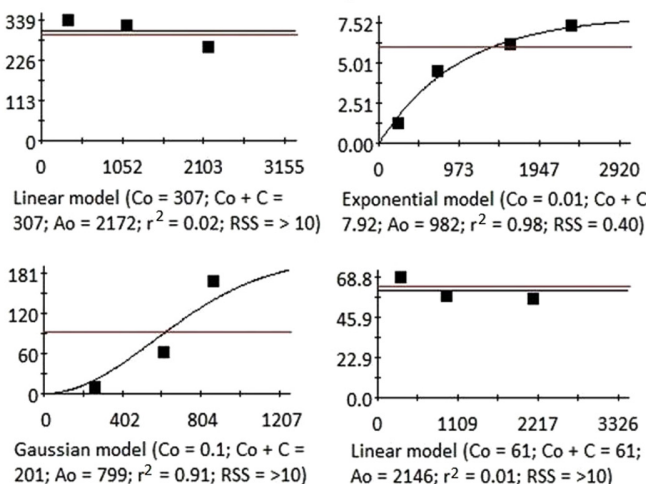

Exponential model $\left(\mathrm{Co}_{0}=0.01 \cdot \mathrm{Co}+\right.$ $7.92 ; A 0=982 ; r^{2}=0.98 ; R S S=0.40$

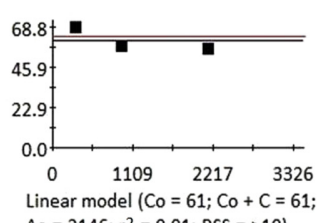

Linear model $(\mathrm{Co}=61 ; \mathrm{Co}+\mathrm{C}=$

$\mathrm{NO}_{3}(\mathrm{mg} / \mathrm{L})$

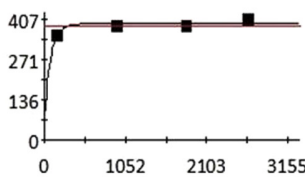

ponential model $\left(\mathrm{CO}_{\mathrm{O}}=70 ; \mathrm{CO}+\mathrm{C}\right.$ $390 ; A 0=81 ; r^{2}=0.80 ; R S S=>10$ )

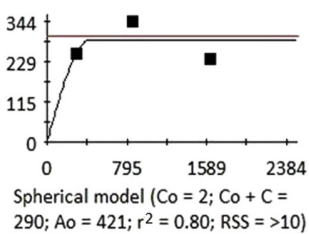

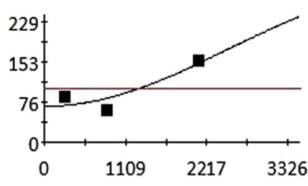

Gaussian model $\left(C_{0}=68 ; C_{0}+C\right.$ $229 ; \mathrm{Ao}=3326 ; \mathrm{r}^{2}=0.82 ; \mathrm{RSS}=>10$

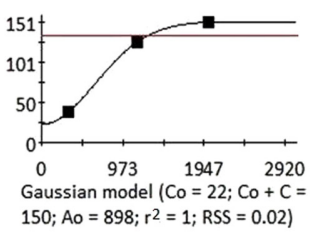

2014

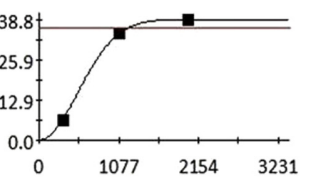

Gaussian model $(\mathrm{Co}=0.10 ; \mathrm{Co}+\mathrm{C}=$

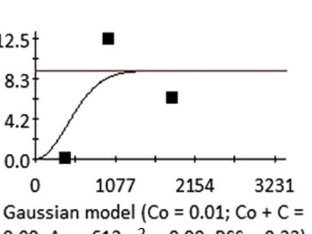

9.09: $A 0=612 ; r^{2}=0.80 ;$ RSS $\left.=0.33\right)$

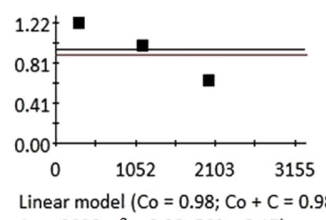

Linear model $\left(\mathrm{CO}_{0}=0.98 ; \mathrm{Co}+\mathrm{C}=0.98\right.$ $A_{0}=2028 ; r^{2}=0.99 ;$ RSS $=0.17$ )

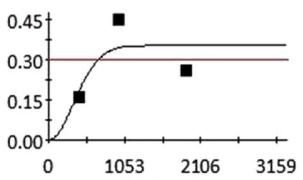

$1053 \quad 2106 \quad 3159$ Gaussian model $(\mathrm{Co}=0.001 ; \mathrm{Co}+\mathrm{C}=$ $0.35 ; A 0=496 ; r^{2}=0.80 ; R S S=0.02$ )

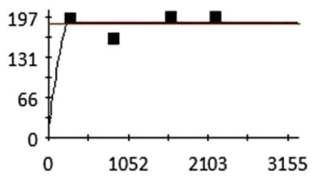

Spherical model $\left(C_{0}=16 \cdot C_{0}+C=\right.$ $187 ; A 0=277 ; r^{2}=0.20 ; R S S=>10$ )

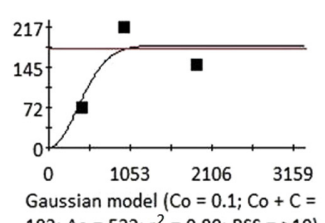

182; $A 0=532 ; r^{2}=0.80 ;$ RSS $=>10$
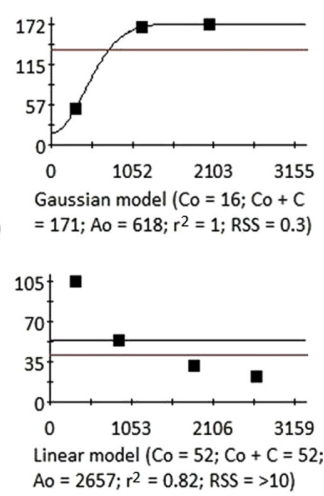

Separation distance $(\mathrm{m})$

Figure 2. Semivariogram for groundwater level below ground surface, $\mathrm{pH}, \mathrm{EC}$, and $\mathrm{NO}_{3}$ in rainy and dry seasons from 2011 to $2014 . \mathrm{Red}$ line represents sample variance and black line shows variogram model. $C_{0}:$ Nugget variance; $C_{0}+C:$ Structural variance sill; $A:$ Range; $r^{2}:$ Coefficient of determination; RSS: Residual sum of squares; n.a.: Not available. 
seasons of year 2013. This indicates that spatial heterogeneity in the spatial structure of groundwater level, caused by random aspects was minimal. Increase in nugget variance is followed by increased range value of the theoretical models. Table 2 indicated the spatial structure of groundwater level falls in class of strong spatial dependence during both seasons of the studied years.

Groundwater $\mathrm{pH}$ showed high values of proportion $\mathrm{C}_{0} /\left(\mathrm{C}_{0}+\mathrm{C}\right)$ during dry season of 2011, dry season of 2013, and rainy season of 2014 with pure nugget effect (Fig. 2). The large range of theoretical models followed by high nugget variance, which is indicator of extent of range cannot be measured with present sampling paradigm or due to some experimental errors. The spatial dependence of groundwater $\mathrm{pH}$ structure showed similar pattern of high nugget variance with weak spatial dependence (Table 2).

Spatial structure of EC was weakly spatially dependent in rainy season of 2012 and dry season of 2013, while in other seasons it showed strong spatial dependence (Table 2). During some seasons, strong spatial autocorrelation in the study area is result of pairing made between values in different locations and the values at highest value locations. The spatial structure of EC will follow wider range of classified values. Fig. 2 is showing high range values where pure nugget effect is observed.

Contrary to other variables, spatial structure of $\mathrm{NO}_{3}$ varied highly across the studied period as showed in Fig. 2, differed in theoretical models (Exponential, Gaussian, Linear, and Spherical) and related parameters. Table 2 shows that groundwater $\mathrm{NO}_{3}$ was weakly to partially to strongly spatially dependent. Highest proportions $\mathrm{C}_{0} /\left(\mathrm{C}_{0}+\mathrm{C}\right)$ found in dry season of year 2011 and 2014, specifically in dry season of 2011 indicated presence of short range dissimilarity that could not be measured by the existing sampling paradigm. This nugget effect can be attributed to experimental error, that it was unable to adopt any of the theoretical model and falls in weakly spatially dependent class. Other's proportion $\mathrm{C}_{0} /\left(\mathrm{C}_{0}+\mathrm{C}\right)$ values are indicating partial to strong spatial dependence in dry season of 2012, which gone through same experimental procedures as the values in weakly spatially dependent class. These long range variations in spatial structure of groundwater
$\mathrm{NO}_{3}$ might be an indication of interactions between groundwater nitrogen and $\mathrm{pH}$. A higher $\mathrm{pH}$ value $>7$ can enhance denitrification processes in anaerobic to semi-anaerobic conditions (Glass and Silverstein, 1998).

\section{Spatial Pattern of Groundwater Hydrochemical Vari- ables and $\mathrm{NO}_{3}$}

Maps based on the kriging interpolation of the groundwater level for the ranges $0-5,6-10,11-20$, and $21-30 \mathrm{~m}$ of depths showed that the inconsistency of groundwater level was intermediate and its spatial pattern was in the form of intermediate sized patches (Fig. 3). The variability in groundwater level increased over the years 2011-2014, with deeper water level values. The most extreme changes arisen at some locations in north-western part of the study area, although some locations with shallow groundwater level in the middle portion of the study area remained relatively unchanged. The variation in the areal coverage of groundwater level ranges across the rainy and dry seasons during the studied time period was inconsistent, but generally giving an outlook of shallow groundwater levels during the dry season. This outlook is attributed to differences in use of irrigation water and cropping season. In addition, the first and third year were different from the second and fourth years in climate variable like monsoon precipitation and temperature.

Spatial pattern of $\mathrm{pH}$ was highly different in the first year having wide patches from the last year values with small patches (Fig. 4). The wide patches represents small variations in the $\mathrm{pH}$ value, while the small patches of pattern are showing large variation in $\mathrm{pH}$ values. Areal coverage for $\mathrm{pH} 5.50-6.50$ gradually vanished in the last year and areal coverage of $\mathrm{pH} 8.51-9.50$ appeared in the last year which revealed an increasing trend of $\mathrm{pH}$ value across the studied period. Change in groundwater $\mathrm{pH}$ have influence on groundwater $\mathrm{NO}_{3}$ and $\mathrm{EC}$ value. Groundwater chemical composition is based on its $\mathrm{pH}$ value along with other climatic factors. For example, in this case, increased $\mathrm{pH}$ in the study area from low to high, will result in increase of denitrification process to minimize $\mathrm{NO}_{3}$ concentrations.

The kriging map of groundwater EC is showing drastic changes in

Table 2. Spatial dependence of groundwater level below ground surface, $\mathrm{pH}, \mathrm{EC}$, and $\mathrm{NO}_{3}$ in wet and dry seasons from 2011 to 2014

\begin{tabular}{|c|c|c|c|c|c|c|c|c|}
\hline Parameter & GWL (m) & $\mathrm{pH}$ & $\mathrm{EC}(\mu \mathrm{S} / \mathrm{cm})$ & $\mathrm{NO}_{3}(\mathrm{mg} / \mathrm{L})$ & GWL (m) & $\mathrm{pH}$ & $\mathrm{EC}(\mu \mathrm{S} / \mathrm{cm})$ & $\mathrm{NO}_{3}(\mathrm{mg} / \mathrm{L})$ \\
\hline 2011 & \multicolumn{4}{|c|}{ Rainy season (June-August) } & \multicolumn{4}{|c|}{ Dry season (September-May) } \\
\hline Proportion $(\mathrm{Co} /[\mathrm{Co}+\mathrm{C}])$ & 0.12 & 2.90 & 2.97 & 17 & 0.03 & 25 & 0.11 & n.a. \\
\hline Spatial dependence & Strong & Strong & Strong & Partial & Strong & Partial & Strong & Weak \\
\hline \multicolumn{9}{|c|}{2012} \\
\hline Proportion $(\mathrm{Co} /[\mathrm{Co}+\mathrm{C}])$ & 0.006 & 2.90 & 100 & 18 & 0.09 & 2.38 & 0.04 & 0.68 \\
\hline Spatial dependence & Strong & Strong & Weak & Partial & Strong & Strong & Strong & Strong \\
\hline \multicolumn{9}{|c|}{2013} \\
\hline Proportion $(\mathrm{Co} /[\mathrm{Co}+\mathrm{C}])$ & 3.60 & 4 & 0.12 & 30 & 5.60 & 100 & 100 & 15 \\
\hline Spatial dependence & Strong & Strong & Strong & Partial & Strong & Weak & Weak & Partial \\
\hline \multicolumn{9}{|c|}{2014} \\
\hline Proportion $(\mathrm{Co} /[\mathrm{Co}+\mathrm{C}])$ & 0.25 & 100 & 8.55 & 91 & 0.11 & 0.28 & 0.05 & 100 \\
\hline Spatial dependence & Strong & Weak & Strong & Partial & Strong & Strong & Strong & Weak \\
\hline
\end{tabular}

$\mathrm{C}_{0}$ : Nugget variance; $\mathrm{C}_{0}+\mathrm{C}$ : Structural variance sill; n.a.: Not available. 

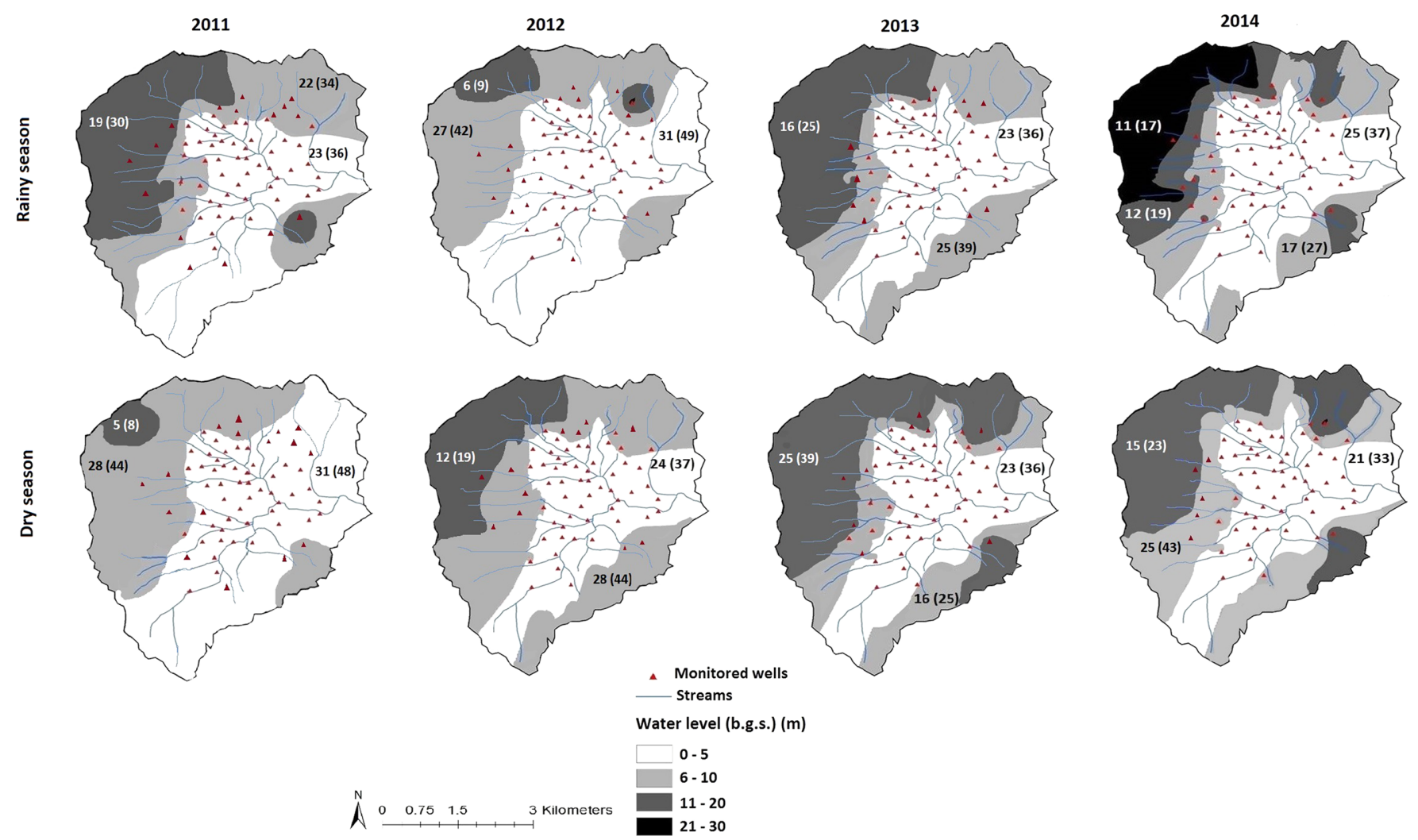

Figure 3. Spatial pattern of groundwater level below ground surface across different seasons from 2011 to 2014 . Areal surface coverage is given in $\mathrm{km}^{2}$ along with percentage (\%) in the study area.
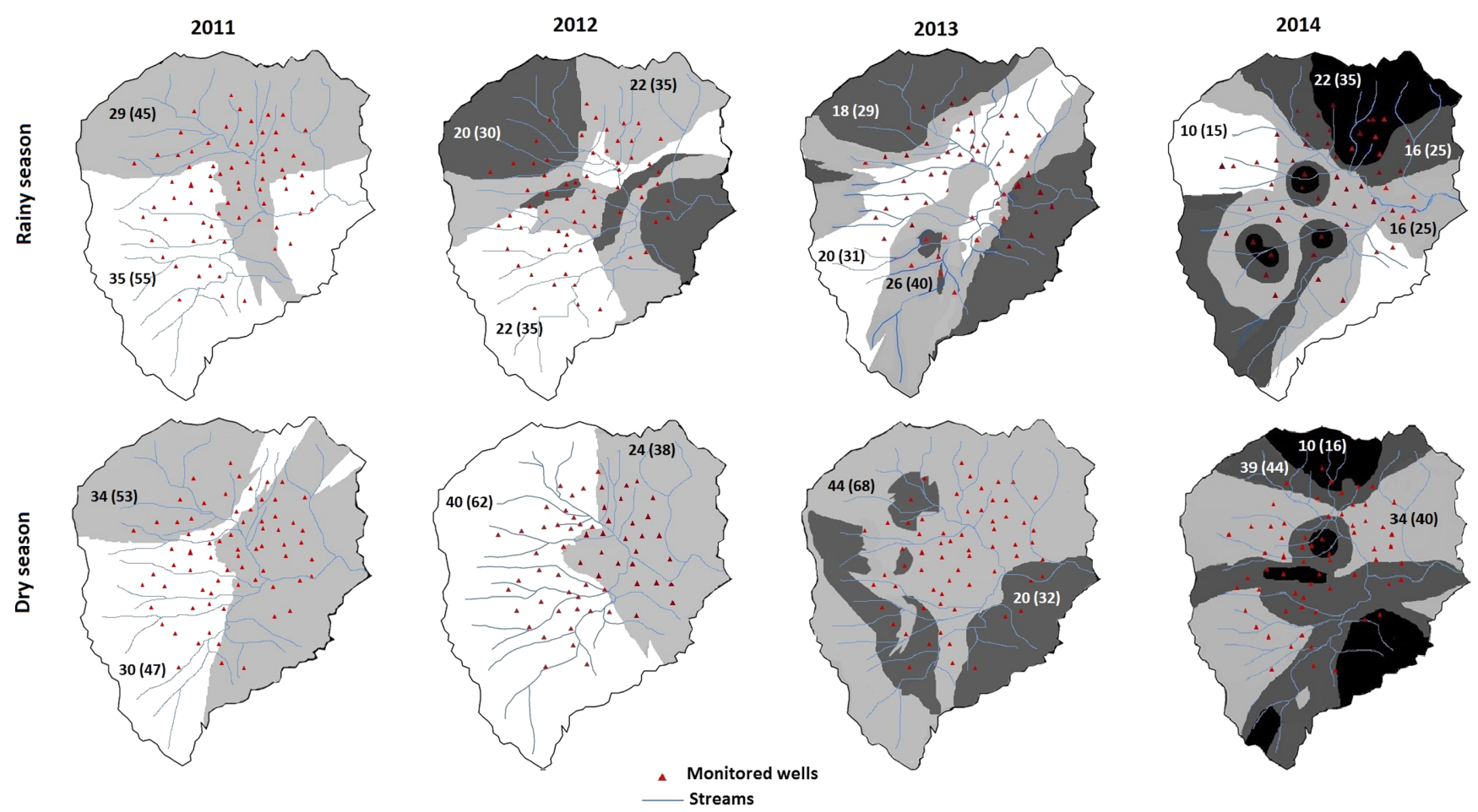

$$
\begin{aligned}
& \text { pH }
\end{aligned}
$$

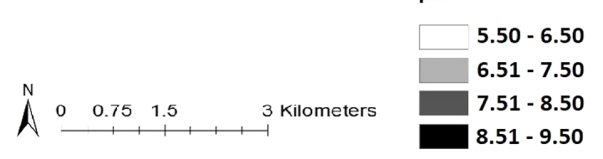

Figure 4. Spatial pattern of groundwater pH in different seasons for the period of 2011-2014. Areal surface coverage is given in $\mathrm{km}^{2}$ along with percentage (\%) in the study area. 

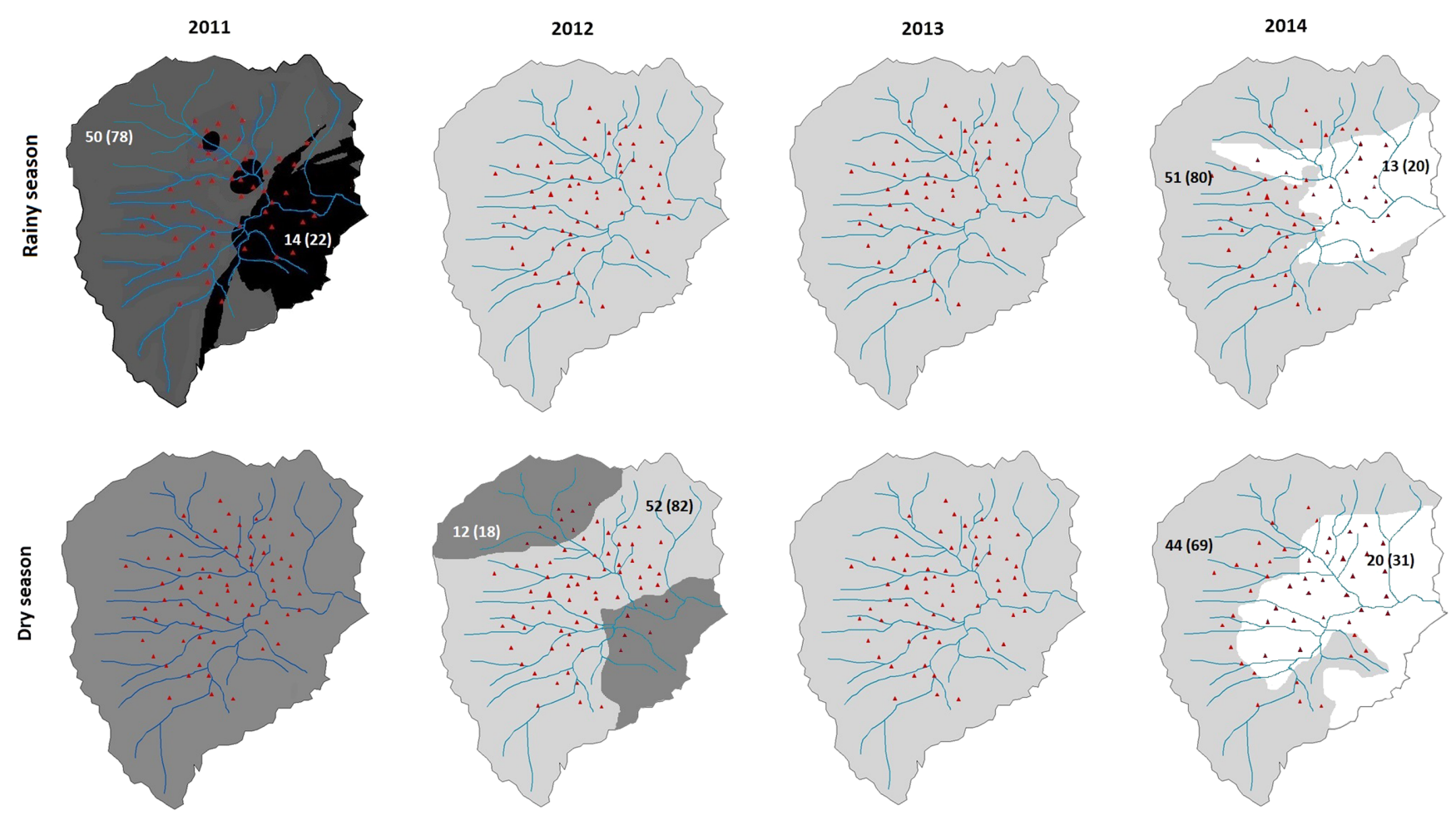

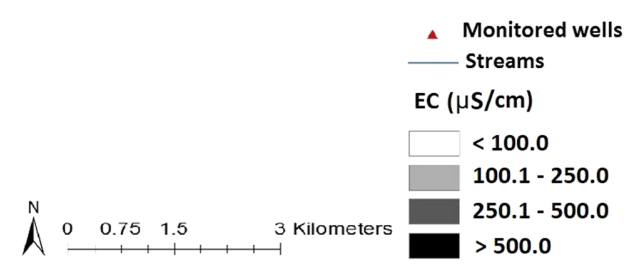

Figure 5. Pattern of spatial variations in groundwater EC $(\mu \mathrm{S} / \mathrm{cm})$ during different seasons from 2011 to 2014. Areal surface coverage is given in $\mathrm{km}^{2}$ along with percentage (\%) in the study area.

its spatial pattern in the study area (Fig. 5). Variations in the EC values remained low within a season, but shifted from high range EC ( $>500 \mu \mathrm{S} / \mathrm{cm})$ to lower range $(<100 \mu \mathrm{S} / \mathrm{cm})$ from 2011 to 2014 . The United States Salinity Laboratory categorized groundwater based on EC values as; excellent $(<25 \mu \mathrm{S} / \mathrm{cm})$, good $(25-75 \mu \mathrm{S} / \mathrm{cm})$, fair (75$225 \mu \mathrm{S} / \mathrm{cm})$, and poor $(>225 \mu \mathrm{S} / \mathrm{cm})$ (Kottureshwara et al., 2014). Results of this study exhibited that poor groundwater disappeared after 2012, and good to excellent groundwater appeared in 2014. This trend is attributed to increasing $\mathrm{pH}$ values across the period of study and intra seasonal variations are accredited to varied monsoon precipitations and over use of groundwater which concentrated the groundwater EC values.

Seasonal changes in spatial pattern of groundwater $\mathrm{NO}_{3}$ from 2011 to 2014 are shown in Fig. 6. The areal coverage of different ranges for groundwater $\mathrm{NO}_{3}$ varied differently across the study period. In the first year wider range resulted in small patches of groundwater $\mathrm{NO}_{3}$, while in the last year small variation in groundwater $\mathrm{NO}_{3}$ formed large patches of pattern. Similar to spatial pattern of groundwater EC and contrary to $\mathrm{pH}$, the high values $(>50 \mathrm{mg} / \mathrm{L})$ for groundwater $\mathrm{NO}_{3}$ which appeared in the start of study period, got vanished at the end of study period. These high $\mathrm{NO}_{3}$ values are hazardous for groundwater aquifer, so monitoring of such location is of environmental importance. The locations with high $\mathrm{NO}_{3}$ values appeared at different loca- tions during different seasons and years, indicating that the sources of high values were different every time.

\section{Discussion}

\section{Factors Affecting Groundwater $\mathrm{NO}_{3}$ Concentrations}

Haean basin is one of the active agricultural highland area in the Soyang watershed, a water resource for downgradient Seoul metropolitan population (Lee et al., 2019). In such regions, high concentration of groundwater and surface water $\mathrm{NO}_{3}$ is a problem due to use of inorganic and organic fertilizers. There are number of natural and anthropogenic factors that influence high $\mathrm{NO}_{3}$ in groundwater including fertilizer use, different land use, rate of precipitation during rainy season, and groundwater recharge enhancing $\mathrm{NO}_{3}$ leaching to groundwater (Jang et al., 2017). Some factors control the $\mathrm{NO}_{3}$ in groundwater including $\mathrm{pH}$, denitrifying bacteria, abundance of dissolved oxygen, geological setting that prohibits $\mathrm{NO}_{3}$ leaching to groundwater, area topography, and the amount of precipitation (Ruidisch et al., 2013; Seo et al., 2014). 

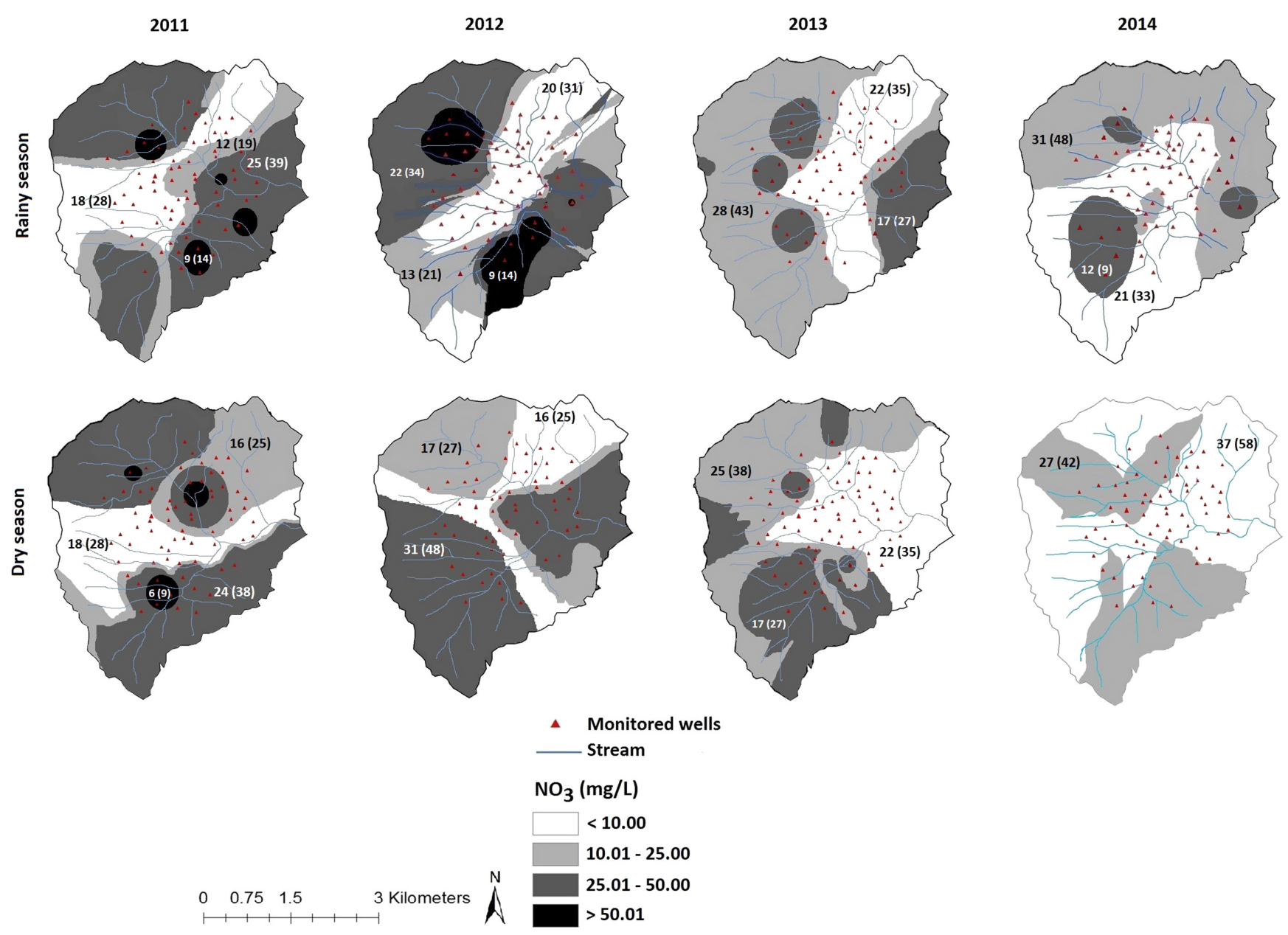

Figure 6. Spatial variation of groundwater $\mathrm{NO}_{3}(\mathrm{mg} / \mathrm{L})$ in rainy and dry seasons from 2011 to 2014. Areal surface coverage is given in $\mathrm{km}^{2}$ along with percentage (\%) in the study area.

\section{Agriculture Activity and Fertilizer use}

Groundwater $\mathrm{NO}_{3}$ pollution is majorly attributed to excessive fertilizer use for high yields in agriculture productions. Haean basin is an intensive agricultural area with multiple land uses have been involved in overuse of fertilizers. In the Haean Catchment fertilizer application contributed to $>90 \%$ of the $\mathrm{NO}_{3}$ inputs and a minor contribution from direct precipitation as compared to annual $\mathrm{N}$-fertilizer use in the agricultural part of Haean basin (Kettering et al., 2012; Suarez et al., 2019). We found groundwater in wells located under vegetable fields had the highest $\mathrm{NO}_{3}$ concentrations (Fig. 6). The elevated groundwater $\mathrm{NO}_{3}$ concentrations are affected by fertilizer leaching from agricultural fields. Particularly in areas with high precipitation rates during monsoon and coarse-textured soils having the potential of $\mathrm{NO}_{3}$ leaching is high (Zotarelli et al., 2007). In study area, topsoil is categorized as a coarse soil texture, which overlies by finer textured subsoil and an underlying dense bedrock material. These situations enriched by the application of sandy soil and fertilizers before growing season (Ruidisch et al., 2013).

The World Health Organization recommended a maximum $\mathrm{NO}_{3}$ concentration of $50 \mathrm{mg} / \mathrm{L}$ in drinking water, while Republic of Korea is even stricter with the maximum concentration of $44.3 \mathrm{mg} / \mathrm{L}$ for $\mathrm{NO}_{3}$ and $10 \mathrm{mg} / \mathrm{L}$ for $\mathrm{NO}_{3}-\mathrm{N}$ in drinking water (Min et al., 2002; Choi et al., 2007; Ruidisch et al., 2013). The Korean government reduced the subsidies for the use of synthetic fertilizers while increased for organic fertilizers, after year 2010. As a result, a decrease in synthetic fertilizers use from 179 to $145 \mathrm{~kg} \mathrm{~N} \mathrm{ha}^{-1} \mathrm{yr}^{-1}$ was observed during the study period (Kim et al., 2015). On the other hand, an increasing use of organic fertilizers from 80 to $129 \mathrm{~kg} \mathrm{~N} \mathrm{ha}^{-1} \mathrm{yr}^{-1}$ was observed during the study period (Yanggu County Office, 2014; Kim et al., 2015). The amount of applied fertilizers was different for different crops grown in the study area (Table 3). The fertilizer application to fields started with the start of crops, and their growing season was approximately same as the monsoon season in the study area. Effect of applied fertil-

Table 3. Annual use of fertilizers in main crops of the Haean Basin (Yanggu County Office, 2014)

\begin{tabular}{|c|c|c|}
\hline Crop & $\begin{array}{c}\text { Fertilizer use } \\
\left(\mathrm{kg} \mathrm{N} \mathrm{ha}^{-1} \mathrm{yr}^{-1}\right)\end{array}$ & $\begin{array}{c}\text { Fertilizing frequency } \\
\text { per year }\end{array}$ \\
\hline Chinese cabbage & 238 & Two \\
\hline White radish & 225 & Three \\
\hline Potato & 137 & One \\
\hline Soybeans & 30 & One \\
\hline Rice & 90 & Two \\
\hline
\end{tabular}


izer on groundwater quality starts with leaching of $\mathrm{NO}_{3}$ from soil to groundwater, which is influenced by precipitation in unsaturated zone.

\section{Seasonal Variations}

High seasonal variation of groundwater $\mathrm{NO}_{3}$ were accredited to management practices i.e. time and amount of applied fertilizers, irrigation time and amount of water applied, amount of precipitation. The excessive fertilization of crop fields resulted in elevated groundwater $\mathrm{NO}_{3}$ concentrations owing to leaching losses from crop fields into the groundwater, enforced by monsoonal precipitation (Bartsch et al., 2013, 2014). The accessibility of $\mathrm{NO}_{3}$ can be managed by farmers with their choice of fertilizer application rates, but $\mathrm{NO}_{3}$ leaching is highly dependent on the amount and period of monsoon precipitation (Lee et al., 2014). Variations in precipitation during monsoon season can cause risks in terms of water quality and alterations in hydrological and biogeochemical drivers of $\mathrm{NO}_{3}$ leaching to groundwater, from the applied fertilizers on soil surface (Arnhold et al., 2014; Suarez et al., 2019). The precipitation in the monsoon season fluctuated particularly in the four years of this study (Lee et al., 2019). An estimated rate of $\mathrm{NO}_{3}$ leaching was $>50 \%$ and up to $75 \%$ initiated from fertilized upland fields in the study area (Kim et al., 2015). In addition to by leaching during precipitation, slope of the area may contribute in reduced groundwater $\mathrm{NO}_{3}$ concentrations at higher slopes occupied by forest with absence of fertilizers. An intermediate terrain area comprised of highly fertilized vegetable fields showed high $\mathrm{NO}_{3}$ concentrations in groundwater. Relatively flat area of rice paddies have lower $\mathrm{NO}_{3}$ in groundwater which is attributed to presence of denitrifying bacteria in abundance (Seo et al., 2014; Kim et al., 2015). The variation in seasonal precipitation may not have direct effect on groundwater $\mathrm{NO}_{3}$ but, it can influence the factors controlling $\mathrm{NO}_{3}$ in groundwater (Shope, 2016).

\section{Land Use}

Land use and seasonal variations are interdependent and of equal importance for the groundwater quality in areas under agricultural activities (Bartsch et al., 2013; Ali and Reineking, 2016). Different land uses have different effects on groundwater $\mathrm{NO}_{3}$ as shrub and grasslands have lowest groundwater $\mathrm{NO}_{3}$ values, whereas vegetable fields have higher or highly variable $\mathrm{NO}_{3}$ concentrations in groundwater (PastenZapata et al., 2014). The change in trend from annual to perennial crops assists the reduction of $\mathrm{NO}_{3}$ surplus with spatially limited applications in the future (Ruidisch et al., 2013).

Application of fertilizers to agricultural area caused $>90 \%$ of $\mathrm{NO}_{3}$ surplus in the Haean basin. Leaching and surface runoff were found as the main loss pathways for surplus $\mathrm{NO}_{3}$ (Kettering et al., 2012; Shope and Maharjan, 2015). Among cultivated crops in the study area, radish indicated the highest uptake efficacy $(43-45 \%)$ for $\mathrm{NO}_{3}$, whereas rice showed the lowest uptake efficacy (24-30\%). The observed contribution to $\mathrm{NO}_{3}$ surplus in agricultural land use showed an order as; cabbage $<$ potato $<$ soybean $<$ radish, while ginseng and orchards did not play a substantial role (Ruidisch et al., 2013; Lee et al., 2019). Since 2011, increased perennial crops like ginseng and fruit orchards assumed to have a lower groundwater $\mathrm{NO}_{3}$ due to lower fertilizer inputs, lower leaching, and higher surface runoff at high slopes (Lee et al., 2019).

\section{Varying Hydrochemistry}

The biogeochemical and hydrological processes in the groundwater are based on the chemistry of groundwater. Fig. 7 showed an increase in groundwater level value (groundwater deepening) across the studied period. Deepening of the groundwater level from 2011 to 2014, is attributed to a gradual increase in groundwater abstraction majorly for agricultural activities in Haean basin, which resulted in observable drop of average groundwater level (Raza et al., 2019). Decreasing groundwater $\mathrm{NO}_{3}$ in this study, found to have negative correlation with the increasing groundwater level from the soil surface, because fertilizer application mostly effect the shallow groundwater (Pociene and Pocius, 2005). Lowered groundwater level has less chances of having high $\mathrm{NO}_{3}$ concentration due to anthropogenic activities in active agricultural areas.

An increase of groundwater $\mathrm{pH}$ is important since denitrifying bacteria are able to decontaminate groundwater at higher $\mathrm{pH}$ values (Seo et al., 2014). A microbial analysis supported high occurrences of denitrifying bacteria in groundwater of the paddy rice fields at relatively low elevation area in Haean basin (Kim et al., 2015). Fig. 7 showed an increasing trend of $\mathrm{pH}$ value across the studied period. This situation can lead to decrease in groundwater $\mathrm{NO}_{3}$ concentration, as a result of denitrification in shallow groundwater under the rice fields. A drastic change in $\mathrm{pH}$ from 5.5 to 9.5 in 2014 is attributed to precipitation as source in shallow groundwater during rainy season in the studied area (Lee et al., 2014). Another anthropogenic source of elevated groundwater $\mathrm{pH}$ was found as, corrode pipes of groundwater wells in both shallow and deep groundwater levels (Ann-Chatrin et al., 2017). Interactions between groundwater $\mathrm{pH}$ and $\mathrm{NO}_{3}$ would be additional reason for the $\mathrm{NO}_{3}$ variation in its spatial pattern. The spatial distribution maps indicate a link between two variables as the areas with elevated $\mathrm{pH}$ value have lower $\mathrm{NO}_{3}$ value in groundwater.

This study exhibited that area with good EC in groundwater $(<100$ $\mu \mathrm{S} / \mathrm{cm})$ appeared in 2014 and area with high groundwater EC $(>500$ $\mu \mathrm{S} / \mathrm{cm}$ ) disappeared after the first year. Unnecessary use of fertilizer and irrigation water in agricultural fields are the major factors provoking EC in the groundwater. Presence of chemical species cause high EC and their sources should be identified for mitigation of further harm to groundwater. Under intensive agricultural production, substantial amount of salts can move beyond the root zone, deteriorating below groundwater. Plants uptake good or pure water and leave salts that percolate into groundwater (Chaudhuri and Ale, 2014). In this study, overall spatial and temporal distribution trend of groundwater $\mathrm{EC}$ and $\mathrm{NO}_{3}$ is similar (Fig. 7).

\section{Measures to Reduce Groundwater Nitrate Concentrations}

The pattern with high $\mathrm{NO}_{3}$ concentrations in groundwater vanished toward the end of the studied period. Those high concentration pat-

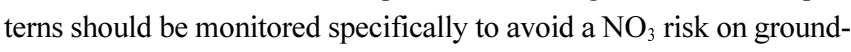
water aquifers and surface water. Difference in appearance and coverage of high $\mathrm{NO}_{3}$ concentration suggesting that the sources of high concentrations were anthropogenic i.e. fertilizer application to agricultural fields.

Numerous measures can be applied to reduce $\mathrm{NO}_{3}$ concentration in groundwater. Soil properties including its water holding capacity and 


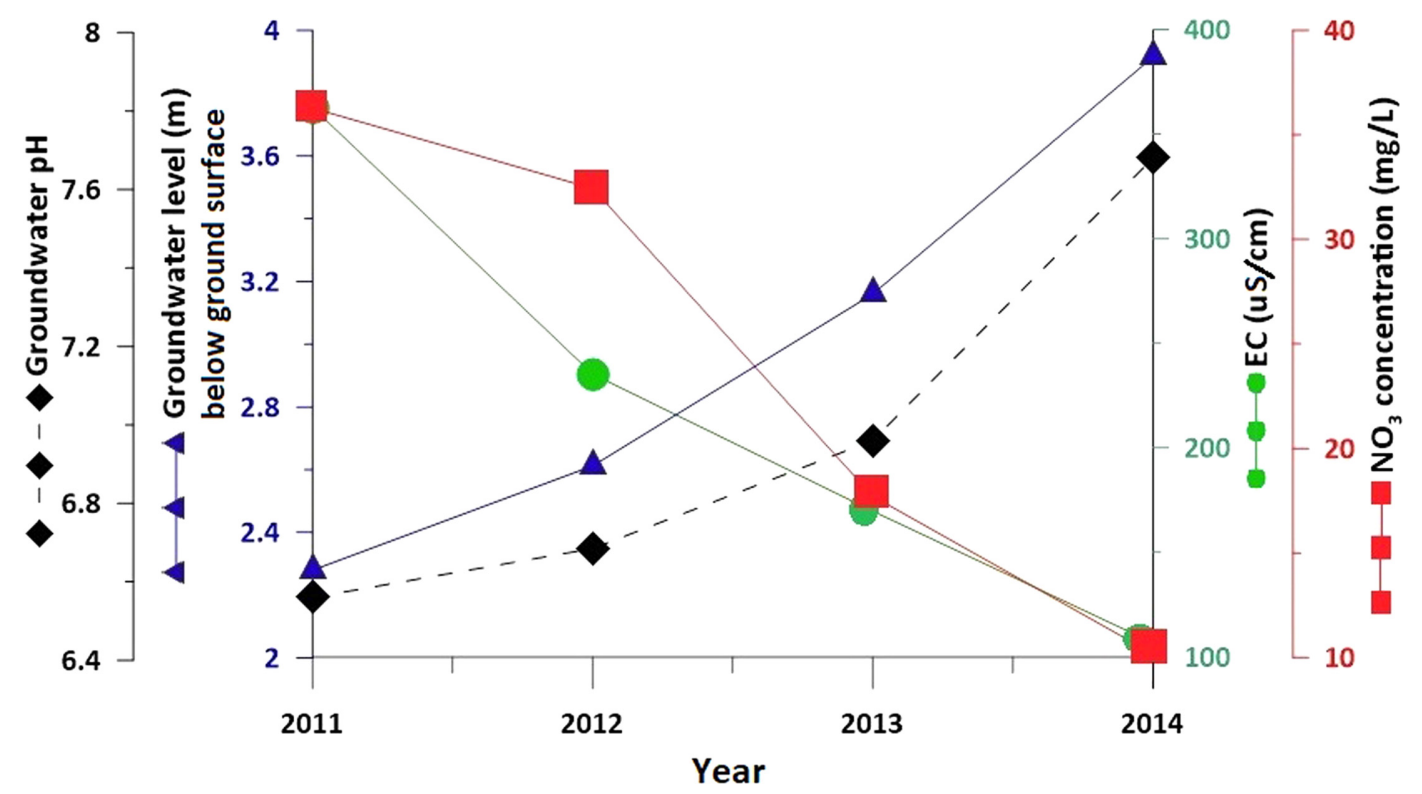

Figure 7. Temporal trend of groundwater hydrochemical variables and $\mathrm{NO}_{3}$ in agricultural Haean Basin.

hydraulic conductivity should be considered before fertilizer application and irrigation, in order to minimize $\mathrm{NO}_{3}$ leaching below the root zone (Ren et al., 2010). Sprinkler irrigation method results in a decreased $\mathrm{NO}_{3}$ leaching as compared to flooded or furrow irrigation method, because water is more uniformly distributed on the soil surface. Rate of water application should be slightly lower than the soil infiltration rate to avoid rapid transport of $\mathrm{NO}_{3}$ to groundwater. Fertilizer application should be in smaller amount but more frequently, particularly during the rainy season, to reduce fertilizer movement to the groundwater. Also, the irrigation water and fertilization amount should be adjusted according to the amount of precipitation during rainy and crop growing season, to avoid $\mathrm{NO}_{3}$ leaching to groundwater. Changing the cropping pattern from crops without plastic or organic mulching to crops with mulching cover would reduce $\mathrm{NO}_{3}$ leaching to groundwater.

The vegetable crops on high elevation fertilized more which results in high $\mathrm{NO}_{3}$ in groundwater. Increasing area for ginseng and orchard land use have reduced the groundwater $\mathrm{NO}_{3}$, but vegetable crops require some best management practices to minimize $\mathrm{NO}_{3}$ in groundwater. A trend of using plastic mulching cover in vegetable fields resulted in $26 \%$ of reduction in $\mathrm{NO}_{3}$ leaching to groundwater, irrespective of applied fertilizer amount and elevation of the area (Berger et al., 2013; Nguyen et al., 2014). All sustainable management practices including split and ridge fertilizer application with plastic mulching cover can reduce the rate of $\mathrm{NO}_{3}$ leached to groundwater.

\section{Conclusions and Required Work}

Variation in temporal trend and spatial distribution of important groundwater hydrochemical variables and $\mathrm{NO}_{3}$ is important for planning sustainable management practices to protect groundwater quality in the Haean basin. The results indicated groundwater high $\mathrm{NO}_{3}$ concentrations under the vegetable field land use at relatively higher elevation.Anthropogenic factor elevating the groundwater $\mathrm{NO}_{3}$ is the excessive use of fertilizers which is influenced by natural and anthropogenic factors including seasonal variation, slope of area, land use, and change in hydrochemical parameters. Areas with high $\mathrm{EC}, \mathrm{pH}$, and $\mathrm{NO}_{3}$ in groundwater should monitored appropriately and implement mitigation measures to control factors that are elevating the groundwater contamination. The results and mitigation measures in this study can be applied to another highland area at catchment scale or with heavy agricultural activities.

A switch from high fertilizer demanding vegetable fields to less fertilizer demanding ginseng and fruit orchards is part of sustainable agriculture practice along with split application and plastic mulching cover. In present and future, there is concern to investigate hydrochemical variables and $\mathrm{NO}_{3}$ in groundwater to draw an appropriate trend. Such trend identification can provide quantitative change of groundwater quality either improved or deteriorated. All considered measures can reasonable reduce the amount of $\mathrm{NO}_{3}$ leached to groundwater, which is of environmental importance. In economic perspective, measures can reduce the net farm productivity like use of plastic mulch and limited fertilization. There should be more practice to find sustainable agriculture measures that are environment friendly with same economic benefits. Groundwater quality can be improved by implementing the mitigation measures, but it is problematic to decide whether adopted measure is sustainable, if we consider the surface water quality as well. Increasing precipitation amount and reduced $\mathrm{NO}_{3}$ leaching to groundwater can result in increased $\mathrm{NO}_{3}$ leaching to stream and river water in the area. There is a need to investigate the effects of measures for improved groundwater quality on the surface water quality of the Haean basin and in the downgradient area.

\section{Acknowledgements}

This work was supported by the National Research Foundation of Korea (NRF) grant, funded by the Korean government (MSIT) (NRF2015R1A4A1041105) and Basic Science Research Program through 
the National Research Foundation of Korea (NRF) funded by the Ministry of Education (NRF-2018R1D1A1B07047200).

\section{References}

Ali, H.E., and Reineking, B., 2016. Extensive management of field margins enhances their potential for off-site soil erosion mitigation. Journal of Environmental Management, v. 169, pp. 202-209.

Ann-Chatrin, N., Geosigma A.B., Bertil, S., and Swerea, K., 2017. Elevated $\mathrm{pH}$ values in groundwater, observations from SKB investigations 1976-2014 and possible causes. Swedish Nuclear Fuel and Waste Management Co. Report SKB R-16-04 January 2017, ISSN 14023091, ID 1533841.

Arnhold, S., Lindner, S., Lee, B., Martin, E., Kettering, J., Nguyen, T.T., Koellner, T., Ok, Y.S., and Huwe, B., 2014. Conventional and organic farming: Soil erosion and conservation potential for row crop cultivation. Geoderma, v. 219, pp. 89-105.

Bartsch, S., Frei, S., Ruidisch, M., Shope, C.L., Peiffer, S., Kim, B., and Fleckenstein, J.H., 2014. River-aquifer exchange fluxes under monsoonal climate conditions. Journal of Hydrology, v. 509, pp. 601-614.

Bartsch, S., Peiffer, S., Shope, C.L., Arnhold, S., Jeong, J.J., Park, J.H., Eum, J., Kim, B., and Fleckenstein, J.H., 2013. Monsoonal-type climate or land-use management: Understanding their role in the mobilization of nitrate and DOC in a mountainous catchment. Journal of Hydrology, v. 507, pp. 149-162.

Belkhiri, L., and Narany, T.S., 2015. Using multivariate statistical analysis, geostatistical techniques and structural equation modeling to identify spatial variability of groundwater quality. Water Resources Management, v. 29, pp. 2073-2089.

Berger, S., Kim, Y., Kettering, J., and Gebauer, G., 2013. Plastic mulching in agriculture-friend or foe of $\mathrm{N}_{2} \mathrm{O}$ emissions?. Agriculture, Ecosystems \& Environment, v. 167, pp. 43-51.

Buczko, U., Kuchenbuch, R.O., and Lennartz, B., 2010. Assessment of the predictive quality of simple indicator approaches for nitrate leaching from agricultural fields. Journal of Environmental Management, v. 91, pp. 1305-1315.

Chaudhuri, S., and Ale, S., 2014. Long term (1960-2010) trends in groundwater contamination and salinization in the Ogallala aquifer in Texas. Journal of Hydrology, v. 513, pp. 376-390.

Choi, W.J., Han, G.H., Lee, S.M., Lee, G.T., Yoon, K.S., Choi, S.M., and Ro, H.M., 2007. Impact of land-use types on nitrate concentration and $\delta 15 \mathrm{~N}$ in unconfined groundwater in rural areas of Korea. Agriculture, Ecosystems and Environment, v. 120, pp. 259-268.

Corwin, D.L., Vaughan, P.J., and Loague, K., 1997. Modeling nonpoint source pollutants in the vadose zone with GIS. Environmental Science and Technology, v. 31, pp. 2157-2175.

De Ruijter, F.J., Boumans, L.J.M., Smit, A.L., and Van den Berg, M., 2007. Nitrate in upper groundwater on farms under tillage as affected by fertilizer use, soil type and groundwater table. Nutrient Cycling in Agroecosystems, v. 77, pp. 155-167.

Fentanes, J.P., Gould, I., Duckett, T., Pearson, S., and Cielniak, G., 2018. $3 \mathrm{D}$ soil compaction mapping through Kriging-based exploration with a mobile robot. arXiv preprint arXiv:1803.08069.

Glass, C., and Silverstein, J., 1998. Denitrification kinetics of high nitrate concentration water: $\mathrm{pH}$ effect on inhibition and nitrite accumulation. Water Research, v. 32, pp. 831-839.

Isaaks, E.H., and Srivastava, R.M., 1989. An introduction to applied geostatistics (No. BOOK). Oxford University Press.

Jang, S.S., Ahn, S.R., and Kim, S.J., 2017. Evaluation of executable best management practices in Haean highland agricultural catchment of South Korea using SWAT. Agricultural Water Management, v. 180, pp. 224-234.

Kaman, H., Cetin, M., and Kirda, C., 2011. Effects of Lower Seyhan Plain irrigation on groundwater depth and salinity. Journal of Food, Agriculture and Environment, v. 9, pp. 648-652.

Kaown, D., Hyun, Y., Bae, G.O., and Lee, K.K., 2007. Factors affecting the spatial pattern of nitrate contamination in shallow groundwater. Journal of Environmental Quality, v. 36, pp. 1479-1487.

Kettering, J., Park, J.H., Lindner, S., Lee, B., Tenhunen, J., and Kuzyakov, Y., 2012. N fluxes in an agricultural catchment under monsoon climate: a budget approach at different scales. Agriculture, Ecosystems and Environment, v. 161, pp. 101-111.

Kim, H., Kaown, D., Mayer, B., Lee, J.Y., Hyun, Y., and Lee, K.K., 2015. Identifying the sources of nitrate contamination of groundwater in an agricultural area (Haean basin, Korea) using isotope and microbial community analyses. Science of the Total Environment, v. 533, pp. $566-575$.

Kim, H., Lee, J.Y., and Lee, K.K., 2013. Spatial and temporal variations of groundwater-stream water interaction in an agricultural area, case study: Haean basin, Korea. Research Journal of Earth and Planetary Sciences, v. 2, pp. 71-82.

Kim, K., Kim, B., Eum, J., Seo, B., Shope, C.L., and Peiffer, S., 2018. Impacts of land use change and summer monsoon on nutrients and sediment exports from an agricultural catchment. Water, v. 10, p. 544.

Kim, Y., Seo, Y., Kraus, D., Klatt, S., Haas, E., Tenhunen, J., and Kiese, R., 2015. Estimation and mitigation of $\mathrm{N}_{2} \mathrm{O}$ emission and nitrate leaching from intensive crop cultivation in the Haean catchment, South Korea. Science of the Total Environment, v. 529, pp. 40-53.

Ko, J., Kim, H.Y., Jeong, S., An, J.B., Choi, G., Kang, S., and Tenhunen, J., 2014. Potential impacts on climate change on paddy rice yield in mountainous highland terrains. Journal of Crop Science and Biotechnology, v. 17, pp. 117-126.

Kottureshwara, N.M., Manjappa, S., Suresh, T., and Jayashree, M., 2014. Status of groundwater quality of Kudligi taluk area in Bellary district, Karnataka, India. International Journal of Pharmacy and Life Sciences, v. 5, pp. 3467-3473.

Kumar, V., 2007. Optimal contour mapping of groundwater levels using universal kriging-a case study. Hydrological Sciences Journal, v. 52, pp. 1038-1050.

Kurunc, A., Ersahin, S., Sonmez, N.K., Kaman, H., Uz, I., Uz, B.Y., and Aslan, G.E., 2016. Seasonal changes of spatial variation of some groundwater quality variables in a large irrigated coastal Mediterranean region of Turkey. Science of the Total Environment, v. 554, pp. 53-63.

Lee, J.Y., Raza, M., and Kwon, K.D., 2019. Land use and land cover changes in the Haean Basin of Korea: Impacts on soil erosion. Episodes Journal of International Geoscience, v. 42, pp. 17-32.

Lee, J.Y., Raza, M., and Park, Y.C., 2018. Current status and management for the sustainable groundwater resources in Korea. Episodes Journal of International Geoscience, v. 41, pp. 179-191.

Lee, J.Y., Kwon, K.D., Park, Y.C., and Jeon, W.H., 2017. Unexpected nationwide nitrate declines in groundwater of Korea. Hydrological Processes, v. 31, pp. 4693-4704.

Lee, J.Y., Lee, K.S., Park, Y., Choi, H.M., and Jo, Y.J., 2013. Chemical and isotopic compositions of groundwater and stream water in a heavy agricultural basin of Korea. Journal of the Geological Society of India, v. 82 , pp. $169-180$.

Lee, J.M., Park, Y.S., Kum, D., Jung, Y., Kim, B., Hwang, S.J., Kim, H.B., Kim, C., and Lim, K.J., 2014. Assessing the effect of watershed slopes on recharge/base flow and soil erosion. Paddy and Water Environment, v. 12, pp. 169-183.

Lee, J.Y., Lim, H.S., Yoon, H.I., and Park, Y., 2013. Stream water and groundwater interaction revealed by temperature monitoring in agricultural areas. Water, v. 5, pp. 1677-1698.

Lim, C.H., Yoo, S., Choi, Y., Jeon, S.W., Son, Y., and Lee, W.K., 2018. Assessing climate change impact on forest habitat suitability and diversity in the Korean Peninsula. Forests, v. 9, p. 259.

Lord, E.I., Anthony, S.G., and Goodlass, G., 2002. Agricultural nitrogen balance and water quality in the UK. Soil Use and Management, v. 18, 
pp. 363-369.

Min, J.H., Yun, S.T., Kim, K.J., Kim, H. S., Hahn, J.S., and Lee, K.S., 2002. Nitrate contamination of alluvial groundwaters in the Nakdong River basin, Korea. Geoscience Journal, v. 6, pp. 35-46.

Nguyen, T.T., Ruidisch, M., Koellner, T., and Tenhunen, J., 2014. Synergies and tradeoffs between nitrate leaching and net farm income: The case of nitrogen best management practices in South Korea. Agriculture, Ecosystems and Environment, v. 186, pp. 160-169.

Pasten-Zapata, E., Ledesma-Ruiz, R., Harter, T., Ramirez, A.I., and Mahlknecht, J., 2014. Assessment of sources and fate of nitrate in shallow groundwater of an agricultural area by using a multi-tracer approach. Science of the Total Environment, v. 470, pp. 855-864.

Pociene, A., and Pocius, S., 2005. Relationship between nitrate amount in groundwater and natural factors. Journal of Environmental Engineering and Landscape Management, v. 13, pp. 23-30.

Powlson, D.S., Addiscott, T.M., Benjamin, N., Cassman, K.G., De Kok, T.M., Van Grinsven, H., Lhirondel, J.L., Avery, A.A., and Van Kessel, C., 2008. When does nitrate become a risk for humans?. Journal of Environmental Quality, v. 37, pp. 291-295.

Rankinen, K., Salo, T., and Granlund, K., 2007. Simulated nitrogen leaching, nitrogen mass field balances and their correlation on four farms in south-western Finland during the period 2000-2005. Agricultural and Food Science, v. 16, pp. 387-406.

Raza, M., Lee, J.Y., and Kwon, K.D., 2019. Estimation of quantitative spatial and temporal distribution for groundwater storage in agricultural basin of Korea: implications for rational water use. Environmental Earth Sciences, v. 78, p.169

Ren, T., Christie, P., Wang, J., Chen, Q., and Zhang, F., 2010. Root zone soil nitrogen management to maintain high tomato yields and minimum nitrogen losses to the environment. Scientia Horticulturae, v. 125, pp. 25-33.

Ruidisch, M., Arnhold, S., Huwe, B., and Bogner, C., 2013. Is ridge cultivation sustainable? A case study from the Haean catchment, South Korea. Applied and Environmental Soil Science, 2013, 679467.

Ruidisch, M., Bartsch, S., Kettering, J., Huwe, B., and Frei, S., 2013. The effect of fertilizer best management practices on nitrate leaching in a plastic mulched ridge cultivation system. Agriculture, Ecosystems and Environment, v. 169, pp. 21-32.

Schroder, J.J., Scholefield, D., Cabral, F., and Hofman, G., 2004. The effects of nutrient losses from agriculture on ground and surface water quality: the position of science in developing indicators for regulation. Environmental Science and Policy, v. 7, pp. 15-23.

Salo, T., and Turtola, E., 2006. Nitrogen balance as an indicator of nitrogen leaching in Finland. Agriculture, Ecosystems and Environment, v. 113, pp. 98-107.

Seo, J., Jang, I., Gebauer, G., and Kang, H., 2014. Abundance of methanogens, methanotrophic bacteria, and denitrifiers in rice paddy soils. Wetlands, v. 34, pp. 213-223.

Sheikhy, N.T., Ramli, M.F., Aris, A.Z., Sulaiman, W.N.A., and Fakharian, K., 2013. Spatial assessment of groundwater quality monitoring wells using indicator kriging and risk mapping, Amol-Babol Plain, Iran. Water, v. 6, pp. 68-85.

Shope, C.L., 2016. Disentangling event-scale hydrologic flow partitioning in mountains of the Korean Peninsula under extreme precipitation. Journal of Hydrology, v. 538, pp. 399-415.

Shope, C.L., and Maharjan, G.R., 2015. Modeling spatiotemporal precipitation: effects of density, interpolation, and land use distribution. Advances in Meteorology, v. 2015, pp. 174196.

Shope, C.L., Maharjan, G.R., Tenhunen, J., Seo, B., Kim, K., Riley, J., Arnhold, S., Koellner, T., Ok, Y.S., Peiffer, S., and Kim, B., 2014. Using the
SWAT model to improve process descriptions and define hydrologic partitioning in South Korea. Hydrology and Earth System Sciences, v. 18 , p. 539-557.

Sieling, K., and Kage, H., 2006. N balance as an indicator of $\mathrm{N}$ leaching in an oilseed rape-winter wheat-winter barley rotation. Agriculture, Ecosystems and Environment, v. 115, pp. 261-269.

Suarez, S.P., Peiffer, S., and Gebauer, G., 2019. Origin and fate of nitrate runoff in an agricultural catchment: Haean, South Korea-Comparison of two extremely different monsoon seasons. Science of the Total Environment, v. 648, pp. 66-79.

Wick, K., Heumesser, C., and Schmid, E., 2012. Groundwater nitrate contamination: factors and indicators. Journal of Environmental Management, v. 111, pp.178-186.

World Health Organization, 2011. Nitrate and nitrite in drinking water. WHO guidelines for drinking-water quality. World Health Organization, pp. 227-231.

Yanggu County Office, 2014. Statistics annual report. http://www.yanggu. go.kr (Accessed on October 05, 2018).

Yun, S.W., Jeon, W.H., and Lee, J.Y., 2017. Evaluation of hydrochemical characteristics of groundwater and stream water in a heavy agricultural region of the Haean basin, Korea. Journal of the Geological Society of Korea, v.53, pp. 727-742.

Zotarelli, L., Scholberg, J.M., Dukes, M.D., and Munoz-Carpena, R., 2007. Monitoring of nitrate leaching in sandy soils. Journal of Environmental Quality, v. 36, pp. 953-962.

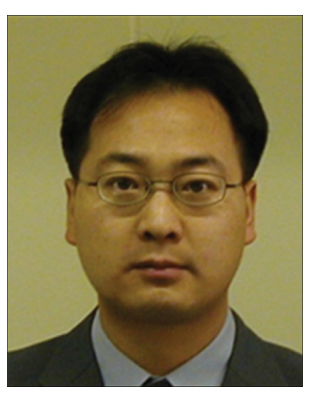

Jin-Yong Lee is a Professor at Kangwon National University. He has published over 200 research papers in international and Korean journals. He was awarded the Young Geologist Award, the Commendation Award from Environment Minister, Academic Award and Best Paper Award from The Geological Society of Korea, Academic Award from Korea Federation of Water Science and Engineering Societies, Academic and Contribution Awards from the Korean Society of Soil and Groundwater Environment, Commendation Award from Minister of Science and ICT, and Order of Science and Technological Merit from President of Republic of Korea. He has served as Editor in Chief for the Journal of the Geological Society of Korea, Associate Editor for Geoscience Journal and Editor in Chief for Episodes, Journal of International Geoscience.

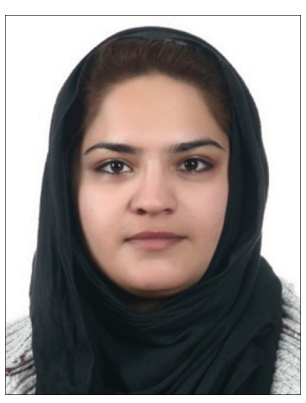

Maimoona Raza is a Ph.D. candidate in the Department of Geology at Kangwon National University. Her research has been concerned with groundwater and the soil environment, with keen interest in identification of groundwater quantity and quality for better management practices. She won the award of best student poster in Hydrological Science section during AOGS-2018 held in Hawaii, the United States of America. She has published seven papers in international journals. 